\title{
STROPHARIA COELHOI (BASIDIOMYCOTA): A NEW SPECIES FROM BRAZIL
}

\author{
Cristiane Seger ${ }^{1}$, Marcelo A. Sulzbacher ${ }^{2}$ \& Vagner G. Cortez $z^{1,3}$ \\ IPrograma de Pós-Graduação em Botânica, Universidade Federal do Paraná, P.O. Box 19031, CEP 81531-980 \\ Curitiba, Paraná,Brazil; crizseger@yahoo.com.br (autor corresponsal). \\ ${ }^{2}$ Universidade Federal de Santa Maria, Laboratório de Microbiologia e Biologia do Solo e Ambiente, Av. Roraima, \\ 1000, Camobi, CEP 97105-900 Santa Maria, Rio Grande do Sul, Brazil. \\ ${ }^{3}$ Universidade Federal do Paraná, Departamento de Biodiversidade, Rua Pioneiro 2153, Jardim Dallas, CEP \\ 85950-000 Palotina, Paraná, Brazil.
}

\begin{abstract}
Seger, C; M. A. Sulzbacher \& V. G. Cortez. 2016. Stropharia coelhoi (Basidiomycota): a new species from Brazil. Darwiniana, nueva serie 4(1): 132-137.

A new species of Stropharia is described from the Atlantic Forest of Rio Grande do Sul State, in southern Brazil. Stropharia coelhoi is distinguished by the smooth dark brown pileus, the presence of hymenial acanthocytes, cheilocystidia and pleurocystidia as chrysocystidia type, and the basidiospore's size. We include photographs and a taxonomical discussion of the new species.
\end{abstract}

Keywords. Agaricales, Araucaria angustifolia, mycobiota, Neotropical fungi.

Resumen. Seger, C; M. A. Sulzbacher \& V. G. Cortez. 2016. Stropharia coelhoi (Basidiomycota): nueva especie de Brasil. Darwiniana, nueva serie 4(1): 132-137.

Se describe una nueva especie de Stropharia para el Bosque Atlántico del estado de Rio Grande do Sul, en el sur del Brasil. Stropharia coelhoi se distingue por su píleo liso, de color castaño oscuro, presencia de acantocitos en las láminas, queilocistidios y pleurocistidios del tipo crisocistidios y el tamaño de las esporas. Se incluyen fotografías de la nueva especie y se discute su taxonomía.

Palabras clave. Agaricales, Araucaria angustifolia, hongos neotropicales, micobiota.

\section{INTRODUCTION}

Stropharia (Fr.) Quél. is a genus of agaricoid, mushroom-forming fungi, which are characterized by the presence of partial veil usually forming an annulus or leaving remnants at the pileus margin, adnate to adnexed lamellae and well-developed rhizomorphs on stipe base, which are densely covered by spiniform crystals called acanthocytes, the latter considered a diagnostic feature of the genus (Farr, 1980; Cortez \& Silveira, 2008).

Members of the genus are distributed worldwide, being recorded from all the continents; currently a number of 25-30 species has been accepted, and such knowledge is presumed as being too limited yet. Recent taxonomic studies revealed unknown species from Asia (Senthilarasu \& Singh, 2013; 
Tian \& Bau, 2014), Australia (Chang et al., 2006), and America (Desjardin \& Hemmes, 2001; Bandala et al., 2005). In Brazil, the genus is best known from the Atlantic Forest areas of southern and southeastern Brazil (Maia et al., 2015), and recent research in the southernmost state of Rio Grande do Sul resulted on the discovery of new taxa (Cortez \& Silveira, 2007, 2008; Silva et al., 2009).

In the course of our ongoing studies on southern Brazilian agaricoid fungi, we found a new member of Stropharia, whose description is the subject of the present paper.

\section{MATERIALS AND METHODS}

Specimens were collected in two areas of native ombrophilous and seasonal forests, respectively, from the state of Rio Grande do Sul, southern Brazil. In both places, the presence of Araucaria angustifolia (Brazilian or Paraná pine) was remarkable, as dominant element in the landscape of mixed ombrophilous forest (Esmeralda) or as relict in the seasonal deciduous forest (Santa Cruz do Sul) (Fig. 1). The specimens were analyzed macro- and microscopically following standard procedures for agaricoid fungi; color names in macroscopic feature descriptions are from Kornerup \& Wanscher (1978). Microstructures were analyzed with $3 \% \mathrm{KOH}$ solutions and $1 \%$ Congo Red. $Q$ is the ratio between the basidiospores length and width, $Q_{m}$ is the average spore quotient, and $n$ is the number of measured basidiospores/number of analyzed basidiomata/number of collections. Holotype is preserved at the herbarium ICN and additional specimens at the HCP herbarium (Thiers, 2016).

\section{RESULTS}

Stropharia coelhoi C. Seger, Sulzbacher \& Cortez, sp. nov. MycoBank MB 816934. TYPE: Brazil, Rio Grande Do Sul, Esmeralda, Estação Ecológica do Aracuri, 5-VI-2004, M.A. Sulzbacher, J. Putzke \& M.T.L. Putzke 40 (holotype ICN). Fig. 2A-I.

Distinguished from other species of Stropharia by the smooth and dark brown pileus, abundant veil remnants on the pileus margin, basidiospores $10.5-13 \times 6.5-8 \mu \mathrm{m}$, pleuro- and cheilocystidia as chrysocystidia, and presence of scattered acanthocytes in the hymenium and stipe apex.

Pileus 12-24 mm, convex to broadly convex, slightly umbonate, surface smooth, glabrous, wet when fresh, dark brown (7F4) to brown (7E4) on mature basidiomata, margin decurved with abundant white velar remnants. Lamellae adnate with decurrent tooth, near, greyish brown (6D3) becoming dark brown (6F6) in age, lamellulae present, edges straight and conspicuously white (6A1). Stipe 35$51 \times 3-8 \mathrm{~mm}$, central, cylindrical to slightly broader at base; surface dry, slightly fibrillose to scabrose, squamulose below the annulus, white (28A1) at the top to greenish grey (28B2) near base. Veil present covering up the gills in young basidiomata, then producing abundant remnants on the pileus margin of mature specimens, also a floccose annulus on the stipe apex, white (28A1), often fragile and collapsing. Rhizomorphs pale gray (1B1), up to 20 $\mathrm{mm}$ long, present at base and sometimes involving the substrate. Context fleshy, orange white (5A2). Spore print greyish brown (11F3) to violet brown (11F4), as seen on the stipe apex.

Basidiospores 10.5-14 (-14.5) $\times(6-) \quad 6.5-8$ (-9) $\mu \mathrm{m}, Q=1.47-1.87$ (-2), $Q_{m}=1.66, n=83 / 2 / 2$, ellipsoid to oblong in face and side view, apically truncated by a large germ pore $\leq 2.5 \mu \mathrm{m}$, rare slightly eccentric in side-view, brown in $\mathrm{KOH}$, smooth, thick-walled. Basidia 25-38 × 8-12 $\mu \mathrm{m}$, clavate, mainly four-spored but two-spored basidia also present, sterigmata $\leq 3 \mu \mathrm{m}$ long, thinwalled, hyaline; basidioles pyriform becoming clavate to broadly clavate, rounded to subcapitate apex; scattered basidia present in the gill edge. Pleurochrysocystidia 28.5-65 × 6-13 $\mu \mathrm{m}$, clavate, clavate-fusiform, some lanceolate or fusoid, apex rounded or acute, less commnonly mucronate $(\leq 4$ $\mu \mathrm{m}$ long), thin-walled, abundant on the sides of the gills. Cheilochrysocystidia (25-) 30-66.5 × 7-12.5 $\mu \mathrm{m}$, fusiform to subcylindrical, rounded to acute apex, or with short mucronate apex, $(\leq 2 \mu \mathrm{m}$ long), thin-walled, common on gill edge. Pileipellis a cutis, slightly gelatinized, composed of cylindrical, prostrate to anticlinal hyphae, hyaline to yellowish brown in mass, thin-walled, with smooth or incrusted walls, $1.5-9 \mu \mathrm{m}$ diam. Pileal context formed by 


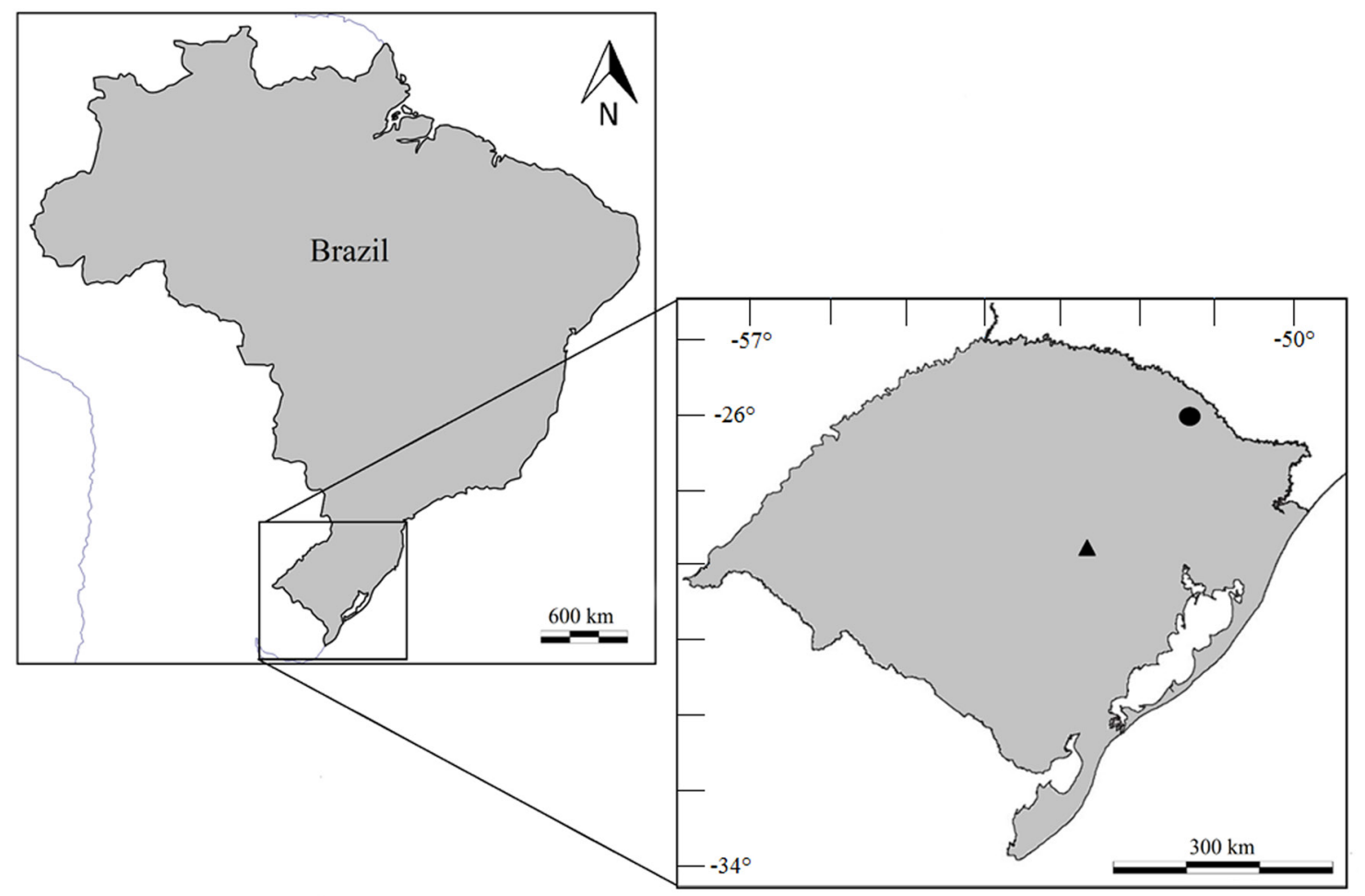

Fig. 1. Populations of Stropharia coelhoi in Brazil, Rio Grande do Sul State, Esmeralda $(\bullet)$ and Santa Cruz do Sul ( $(\Delta)$..

cylindrical to inflated hyphae, interwoven, hyaline, smooth and thin-walled, 5-22 $\mu \mathrm{m}$ diam. Lamella trama subregular, slightly gelatinized, hyaline hyphae, thin-walled to slightly thick-walled, 3.5-11.5 $\mu \mathrm{m}$ diam. Stipitipellis with thin, smooth and hyaline hyphae, 3-6.5 $\mu \mathrm{m}$ diam., bearing bundles of caulocystidia. Stipe trama with cylindrical, subparallel, hyaline hyphae, thin- to slightly thick-walled, 2.5$10 \mu \mathrm{m}$ diam. Cauloleptocystidia 20-44 × 6.5-11 $\mu \mathrm{m}$, clavate to cylindrical, with rounded apex, thinwalled. Chrysovessels present, but rare in the pileus and stipe trama, filled with golden yellow content. Acanthocytes present, abundant on rhizomorphs and scattered in the hymenium and stem. Clamp connections present.

Etymology. Named after Dr. Gilberto Coelho (Universidade Federal de Santa Maria, UFSM), in recognition of his contributions to the knowledge of southern Brazilian macrofungi, especially polypores.
Distribution and habitat. Brazil, Rio Grande do Sul. Solitary or in couples, on soil or rotting wood, in the A. angustifolia (Brazilian pine) forest.

Observations. The proposed new species is another A. angustifolia forest inhabitant and, as other recently discovered taxa from this region, it shares some morphological similarities (Cortez \& Silveira, 2007, 2008; Silva et al., 2009). The presence of a brown pileus, the basidiospore features and the presence of cauloleptocystidia remind those of $S$. araucariae Cortez \& R.M. Silveira, but the latter species differs in the fleshy and grooved annulus, the shape of pleurochrysocystidia and cheilochrysocystidia, which are broadly fusoid and bear a rostrate apex, and the presence of cheiloleptocystidia and pileipellis strongly gelatinized; in addition, it is a more robust mushroom (Cortez \& Silveira, 2008).

Stropharia acanthocystis Cortez \& R.M. Silveira and S. apiahyna (Speg.) Cortez \& R.M. Silveira also present hymenial acanthocytes, however their basidiospores are much smaller (up to $8 \times 5 \mu \mathrm{m}$ ), 

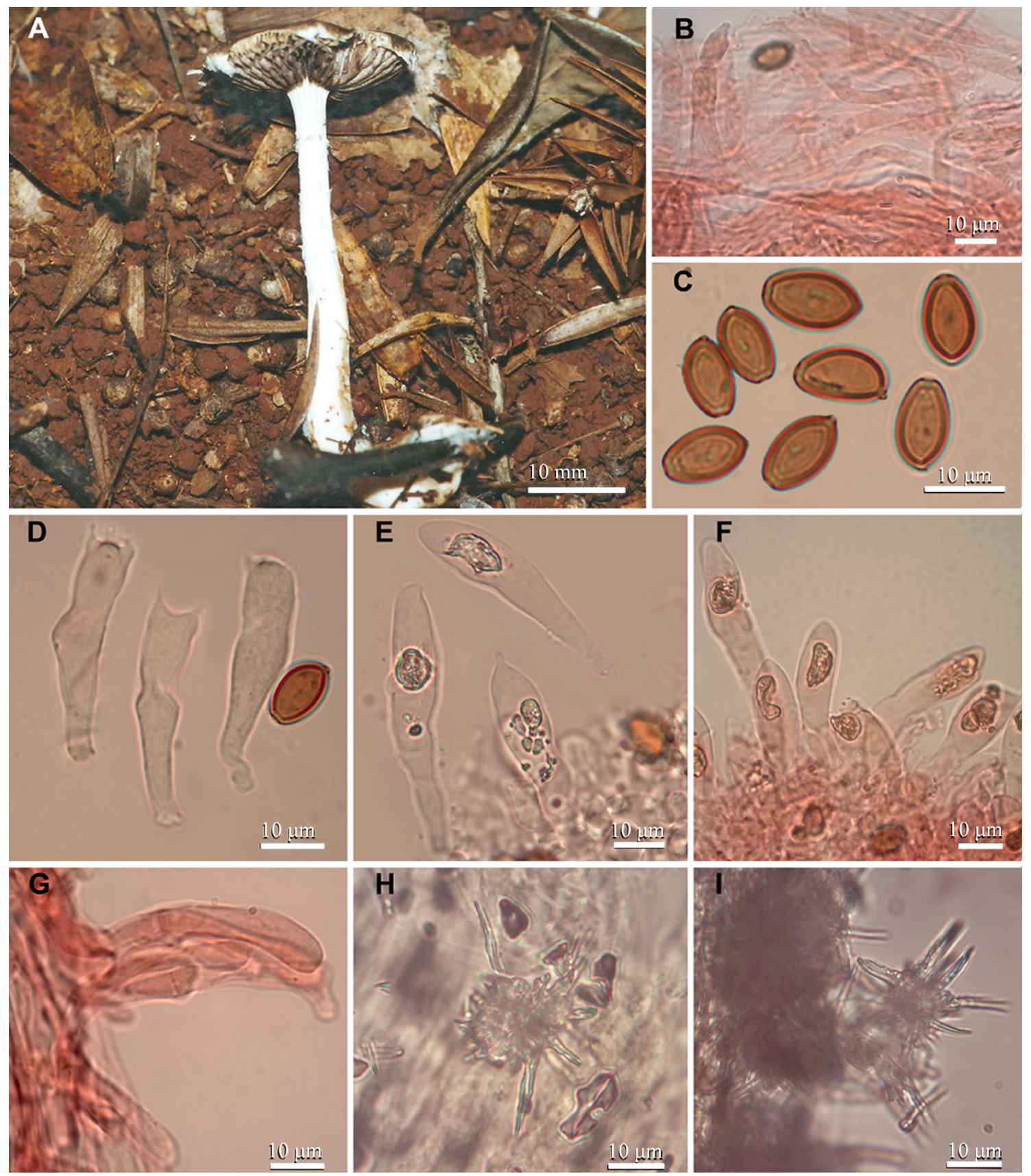

Fig. 2. Stropharia coelhoi. A, basidiomata. B, pileipellis. C, basidiospores. D, basidia. E, pleurocystidia. F, cheilocystidia. G, caulocystidia. H, hymenial acanthocytes. I, acanthocytes on rhizomorphs. From Sulzbacher et al. 40 (ICN). Color version at http;//www.ojs.darwin.edu.ar/index.php/darwiniana/article/view/689/681

yellowish under $\mathrm{KOH}$ and with a reduced and inconspicuous germ pore (Cortez \& Silveira, 2008). The presence of hymenial acanthocytes, presumed by Cortez \& Silveira (2007) as an exclusive feature in $S$. acanthocystis, has now been found in other southern Brazilian species of the genus. They can 
be much scantier or even rare in some species such as $S$. coelhoi and S. apiahyna, or very common and conspicuous as in S. acanthocystis.

Some brownish forms from the northern hemisphere, S. inuncta (Fr.) Quél., are also comparable, since they also exhibit a smooth pileus, partial veil producing a membranous annulus or a fibrillose annular zone, two or four spored basidia, as well similar pleuro- and cheilocystidia (Noordeloos, 2011). However, they differ in the lack of velar remnants on pileus margin, basidiospores slightly smaller with a reduced germ pore, lack of cheilochrysocystidia, and pileipellis with a thick gelatinized layer (Noordeloos, 2011).

Stropharia hornemannii (Fr.: Fr.) Lund. \& Nannf., another species from northern hemisphere, presents umbonate pileus, with abundant velar remnants on margin and producing a floccose annulus; microscopically, it has similar shape and size of the basidiospores and pleurocystidia. The major differences among both species are the more robust and larger basidiomata with yellowish to violaceous tinges of $S$. hornemanii, as well the absence of cheilochrysocystidia and pileipellis strongly gelatinized (Noordeloos, 2011).

\section{Aditional specimen examined}

BRAZIL. Rio Grande do Sul. Santa Cruz do Sul, Parque da Gruta dos Índios, 28-VII-2007, M.A. Sulzbacher \& V.G. Cortez 146/07 (HCP).

\section{DISCUSSION}

In terms of infrageneric classification, Stropharia requires a profound revision, since the proposed taxonomic concepts for subgenera and sections are based mostly on European and North American members (e.g. Singer, 1986; Noordeloos, 2011). In the light of recent data and new described species, some Neotropical taxa (some previously classified in Pholiota) cannot be placed in any of the proposed subgenera/sections. According to Singer (1986) and Noordeloos (2011), Stropharia is divided into three main groups: Stropharia, Mundae e Stercophila - the latter now recognized as an independent genus: Protostropharia Redhead, Moncalvo \& Vilgalys (Redhead, 2013). Stropharia Sect. Stropharia Fr. according to both Singer (1986) and
Noordeloos (2011), is distinguished by subviscid to glutinous pileus, stipe dry, annulus never strongly grooved, may be absent, and chrysocystidia always present. The same authors defined Stropharia Sect. Mundae (Fr.) Konr. \& Maubl. by the subviscid to dry pileus, never glutinous, deeply grooved annulus and chrysocystidia present or absent.

Based on the current classification, S. coelhoi is not appropriately classified in any of the known sections. The surface of the pileus would include this species in Sect. Mundae, but the lack of fleshy and grooved annulus leads to Sect. Stropharia.

Other members of the genus (e.g. S. acanthocystis, $S$. agaricoides and $S$. earlei) are not accordingly classified in the proposed subgenera/sections, since they share morphological features common to both groups. Future studies, including molecular data and the comparison of worldwide materials, are needed to improve the infrageneric classification of Stropharia.

With the discovery of this additional species, we reinforce that diversity of strophariaceous fungi in A. angustifolia forests of southern Brazil remains poorly explored, and the number of species is probably higher than expected. Ongoing studies on Stropharia in southern Brazil will certainly reveal a more diverse mycobiota.

\section{ACKNOWLEDGMENTS}

We thank the financial support of Conselho Nacional de Desenvolvimento Científico e Tecnológico (CNPq, Proc. 483455/2013-3) and Fundação Araucária de Apoio ao Desenvolvimento Científico e Tecnológico do Estado do Paraná (Convênio 675/2014), Coordenação de Aperfeiçoamento de Pessoal de Nível Superior (CAPES) for student fellowship to C.S., and Universidade Federal do Paraná (UFPR) for facilites.

\section{BIBLIOGRAPHY}

Bandala, V. M., L. Montoya \& D. Jarvio. 2005. Agarics from coffee plantations in Eastern Mexico: two new records. Fungal Diversity 20: 17-29.

Chang, Y. S., G. M. Gates \& D. A. Ratkowsky. 2006. Some new species of the Strophariaceae (Agaricales) in Tasmania. Australasian Mycologist 24: 53-68. 


\section{SEGER ET AL. Stropharia coelhoi: a new species from Brazil}

Cortez, V. G. \& R. M. B. Silveira. 2007. A new species of Stropharia with hymenial acanthocytes. Mycologia 99: 135-138. DOI: http://dx.doi.org/10.3852/mycologia.99.1.135

Cortez, V. G. \& R. M. B. Silveira. 2008. The agaric genus Stropharia (Strophariaceae, Agaricales) in Rio Grande do Sul State, Brazil. Fungal Diversity 32: 31-57.

Desjardin, D. E. \& D. E. Hemmes. 2001. Agaricales of the Hawaiian Islands: 7. Notes on Volvariella, Mycena sect. Radiatae, Physalacria, Porpoloma and Stropharia. Harvard Papers in Botany 6: 85-103.

Farr, D. F. 1980. The acanthocyte, a unique cell type in Stropharia (Agaricales). Mycotaxon 11: 241-249.

Kornerup, A. \& K. H. Wanscher. 1978. Methuen Handbook of Colour. $3^{\text {rd }}$ ed. London: Eyre Methuen.

Maia, L. C., A. A. Carvalho Júnior, L. H. Cavalcanti, A. M. Gugliotta, E. R. Drechsler-Santos, A. L. M. A. Santiago, M. S. Cáceres, T. B. Gibertoni, A. Aptroot, A. J. Giachini, A. M. S. Soares, A. C. G. Silva, A. C. Magnago, B. T. Goto, C. R. S. Lira, C. A.S. Montoya, C. L. A. Pires-Zottarelli, D. K. A. Silva, D. J. Soares, D. H. C. Rezende, E. D. M. N. Luz, E. L. Gumboski, F. Wartchow, F. Karstedt, F. M. Freire, F. P. Coutinho, G. S. N. de Melo, H. M. P. Sotão, I. G. Baseia, J. Pereira, J. J. S. Oliveira, J. F. Souza, J. L. Bezerra, L. S. Araujo Neta, L. H. Pfenning, L. F. P. Gusmão, M. A. Neves, M. Capelari, M. C. W. Jaeger, M. P. Pulgarín, N. Menolli Junior, P. S. Medeiros, R. C. S. Friedrich, R. S. Chikowski,
R. M. Pires, R. F. Melo, R. M. B. Silveira, S. Urrea-Valencia, V. G. Cortez \& V. F. Silva. 2015. Diversity of Brazilian fungi. Rodriguésia 66(4): 1033-1045. DOI: http://dx.doi. org/10.1590/2175-7860201566407

Noordeloos, M. E. 2011. Strophariaceae s.1. Fungi Europaei 13. Alassio: Edizioni Candusso.

Redhead, S. A. 2013. Nomenclatural novelties. Index Fungorum 15: 1-2.

Senthilarasu, G. \& S. Singh. 2013. A new species of Stropharia from Western Ghats, India. Mycotaxon 123: 213-220. DOI: http://dx.doi.org/10.5248/123.213

Silva, P. S., V. G. Cortez \& R. M. B. Silveira. 2009. New species of Stropharia from Araucaria angustifolia forests of southern Brazil. Mycologia 101: 539-544. DOI: http://dx.doi. org/10.3852/08-097

Singer, R. 1986. The Agaricales in Modern Taxonomy. $4^{\text {th }}$ ed. Koeltz, Koenigstein.

Thiers, B. [continuing updated]. Index Herbariorum: A global directory of public herbaria and associated staff. New York Botanical Garden's Virtual Herbarium. http://sweetgum. nybg.org/ih/. Accessed: March, 2016.

Tian, E. \& T. Bau. 2014. Stropharia jilinensis, a new species (Strophariaceae, Agaricales) from China. Nova Hedwigia 99: 271-276. DOI: http://dx.doi.org/10.1127/0029$5035 / 2013 / 0141$ 